\title{
Need for a court to rule on patents and misconduct
} Scientific affairs are too complex to be solved locally, says a researcher cleared of fraud.

Sir — Disputes over promotion and control of resource allocation occur in every lab. Fortunately, they rarely end up with the destruction of a solid research team as reported in your News story "Tribunal clears obesity researcher of fraud" (Nature 424, 6; 2003). If all participants had only been willing to follow a few simple rules, the situation could have been avoided.

First, the details of the allegation should have been brought forward immediately. Because these were kept secret for a long time, a simple, transparent scientific debate became impossible. Instead, two adversarial sides emerged. It took five years for a prosecutor and a judge to understand and rule on the matter. French justice was the sole institution able to get to the bottom of this longstanding problem because the law provided it with the full power of disclosure.

Whistleblowers should not be allowed anonymity. The remote possibility of retaliation does not justify secrecy, and protection by the authorities can easily be guaranteed. The openness of the procedure will itself shield the accuser from the accused. Bringing forward an accusation that jeopardizes someone's career requires courage: both the accused and the whistleblower should take responsibility for their actions.

The main lesson to be learned from the whole affair is that any attempt by anyone to maintain any part of an investigation of this type in secrecy is the truth's biggest enemy. Even if the inevitable invasion of privacy is sometimes hard to bear, it is the only way.

Second, although I strongly advocate complete openness when confronted by the inquiry procedure, I also believe that disclosure to the public by journalists does more harm than good. What would have happened had you decided not to publish your stories about this affair? Rennes University would have pursued the case, the judicial inquiry would have been completed, my name would have been cleared and I believe Inserm Unit 391 would have been able to pursue its work. This is not to say that journalists should not report on cases of misconduct. But they should wait until they have definitive evidence. Scientific articles based on circumstantial evidence and not peer-reviewed are not published, because a general audience cannot critically evaluate the data. The same rule should apply to journalism.

Finally, matters such as this one cannot be handled at the local level. I believe the best way forward would be for a court of scientific affairs to be established: possibly at European level. Although there are only a few cases of scientific misconduct, there are many patent disputes that require detailed understanding of science. With the growing industrialization of biology more such disputes are likely to happen. Science is now mixed with large economic and political interests requiring a powerful court of arbitration. Such a court should be staffed by people with impeccable scientific and legal credentials, but with no direct involvement in scientific research policy. Bernard E. Bihain

Médecine et Thérapeutique Moléculaire (MTM), 15 rue du Bois de la Champelle,

54500 Vandoeuvre-les-Nancy, France

\section{Haeckel's literary hopes dashed by materialism?}

Sir - The renewed debate (see, for example, ref. 1) about whether the German zoologist Ernst Haeckel 'doctored' his embryo drawings to fit his biogenetic law - ontogeny recapitulates phylogeny — has led to intensified research into other aspects of Haeckel's life and work. One example is the strange story of when he thought he had been awarded the 1908 Nobel Prize in Literature.

Haeckel was very disappointed when he heard that this prize had gone to the German philosopher Rudolf Eucken. French and Italian newspapers had announced that Haeckel was to be given the prize, and he had received telegrams and postcards congratulating him. Haeckel thought he deserved the prize, and wrote to a friend, the publisher Wilhelm Breitenbach, on 30 November 1908: "If I were to get the Nobel prize (which in view of my 50 years of work and according to the often expressed views of colleagues might be justified!) I would donate the money to the Phyletic Museum."

It was particularly irritating for Haeckel to be beaten by Eucken. On 29 December that year, Haeckel wrote (see page 214 of ref. 2) to his friend and biographer, the popular science writer Wilhelm Bölsche: "I heard from Stockholm that there had actually been a kind of competition in the 'Nobel commission' between myself and my colleague Rudolf Eucken. But the latter won as an advocate of idealism and a priest of the 'higher spiritual world', while I as advocate of materialism and slave to the 'lower Nature' had to lose. Eucken is a popular rhetorician and promoter of the Christian religion, but until now he has not brought any new ideas into philosophy."

Haeckel's belief that he was nominated for a Nobel Prize in Literature is incorrect (see, for example, ref. 3 - research by U.H. and L.O. in Swedish archives was supported by a grant from the Royal Swedish Academy of Sciences' Centre for the History of Science). Among the 16 nominees, the top candidates initially were the Swedish novelist Selma Lagerlöf and the English poet Algernon Charles Swinburne, but the Nobel committee could not make up its mind between these two. Eucken was suggested as a compromise solution by Vitalis Norström, professor of philosophy at Gothenburg University, who admired Eucken's philosophical writings4. These were seen as consistent with the terms of Alfred Nobel's will directing that the literature prize should go to a work written "with an idealistic tendency".

The award of the literature prize to Eucken has been called "the biggest faux pas" in the history of the Nobel prize (see page 63 of ref. 5). Haeckel's conviction that his materialism was unpopular among leading members of the Swedish Academy receives support in a letter dated 27 November 1908 from the historian Harald Hjärne, director of the academy, to the poet and academy member Esaias Tegnér. Hjärne wrote that Eucken was needed "as a counterweight to the demonstrations in support of his Jena colleague Haeckel" (see page 181 of ref. 6) during Uppsala's 1907 bicentennial celebrations for Linnaeus, when a lecture by Haeckel had been enthusiastically received. Uwe Hossfeld ${ }^{\star}$, Rosemarie Nöthlich ${ }^{\star}$, Lennart Olsson $\dagger$

*Institut für Geschichte der Medizin,

Naturwissenschaft und Technik,

Ernst-Haeckel-Haus, Friedrich-Schiller-Universität, Berggasse 7, D-07745 Jena, Germany

$\dagger$ Institut für Spezielle Zoologie und Evolutionsbiologie mit Phyletischem Museum, Friedrich-Schiller-

Universität, Erbertstr. 1, D-07743 Jena, Germany

1. Kemp, M. Nature 395, 447 (1998).

2. Nöthlich, R. Ernst Haeckel-Wilhelm Bölsche: Briefwechsel 1887-1919 (VWB, Berlin, 2002).

3. Svensén, B. Nobelpriset i Litteratur. Nomineringar och utlåtanden 1901-1950. Del. I: 1901-1920 (Norstedts, Stockholm, 2001).

4. Eucken, R. Grundlinien einer neuen Lebensanschauung (Veit, Leipzig, 1907).

5. Lång, H. De litterära Nobelprisen 1901-1983 (Bra Böcker, Höganäs, 1984).

6. Espmark, K. Det litterära Nobelpriset. Principer och värderingar bakom besluten (Norstedts, Stockholm, 1986). 